\title{
Development of piezoelectric immunosensor for the rapid detection of marine derived pathogenic bacteria, Vibrio vulnificus
}

\author{
Suhee Hong and Hyun-Do Jeong ${ }^{*}$ \\ Department of Marine Biotechnology, Gangneung Wonju National University, Gangneung 210-702, KOREA \\ "Department of Aquatic Life Medicine, Pukyong National University, Busan 608-737, KOREA
}

\begin{abstract}
Biosensors consist of biochemical recognition agents like antibodies immobilized on the surfaces of transducers that change the recognition into a measurable electronic signal. Here we report a piezoelectric immunosensor made to detect Vibrio vulnificus. A $9 \mathrm{MHz}$ AT-cut piezoelectric wafer attached with two gold electrodes of $5 \mathrm{~mm}$ diameter was used as the transducer of the QCM biosensor with a reproducibility of $\pm 0.1 \mathrm{~Hz}$ in frequency response. We have tried different approaches to immobilize antibody on the sensor chip. Concerning the orientation of antibody for the best antigen binding capacity, the antibody was immobilized by specific binding to protein $\mathrm{G}$ or by cross-linking through hydrazine. In addition, protein $\mathrm{G}$ was cross-linked on glutaraldehyde activated immine layer (PEI) or EDC/NHS activated sulfide monolayer (MPA). PEI was found to be more effective to immobilize protein $\mathrm{G}$ following glutaraldehyde activation than MPA. However, hydrazine chip showed a better capability to immobilize more IgG than protein $G$ chip and a higher sensitivity. The sensor system was able to detect $V$. vulnificus in dose dependent manner and was able to detect bacterial cells within 5 minutes by monitoring frequency shifts in real time. The detection limit can be improved by preincubation to enrich the bacterial cell number.
\end{abstract}

Key words: QCM, Polyethyleneimine, 3-mercaptopropionic acid, IgG, Protein G, Vibrio vulnificus

Biosensors consist of biochemical recognition agents, like enzymes, antibodies, nucleic acids or chemoreceptors, immobilized on the surfaces of transducers that change the recognition event into a measurable electronic signal. Piezoelctric devices have been proposed as probes that are able to continuously monitor affinity reactions (antigen-antibody, DNA hybridisation reaction, etc.), without the use of any label (Minunni et al., 1995; Guilbault et al., 1992; Skladal et al., 1994). The first use of antigens as coating in quartz crystal microbalances (QCM) was proposed by Shons et al. (1972). Since then, QCM has

\footnotetext{
${ }^{\dagger}$ Corresponding author: Hyun-Do Jeong

Tel: 82-51-629-5941, Fax: 82-51-629-5938

E-mail: jeonghd@pknu.ac.kr
}

been developed as an extremely sensitive mass sensor, able of measuring subnanogram levels (Clark et al., 1989). The detection limits can be improved by using crystals of higher frequencies $(>10 \mathrm{MHz})$ (Bunde et al., 1998; Lin et al., 1993) and improving the immobilization procedure on the quartz surface (Clark et al., 1989).

The easiest and quickest way to immobilise proteins onto the gold surface of quartz crystals is physical adsorption due to their hydrophobic properties (Absolom et al., 1987). Generally, it can be assumed that the biomolecule attachment to gold occurs via binding of the protein disulfide groups (Horisberger and Vauthey, 1984). This modification scheme is fast and simple, but the mechanism of protein adsorption is affected by many physical and chemical factors re- 
garding the protein, the metal surface and the solvent (Matsamura and Kleijin, 1993).

Traditional methods for antibody immobilization on the gold surface of a piezoelectric quartz crystal include coating with protein A (Minunni et al., 1995; Guilbault et al., 1992; Boveniser et al., 1998; Attili and Suleiman, 1995) or silanisation, usually with aminopropyltriethoxysilane and activation with glutaraldehyde (Muramatsu et al., 1987; Steegborn and Skladal, 1997). Different polymers have also been used including polyethyleneimine (Konig and Gratzel, 1993; Prusak-Sochaczewski et al., 1990)

Many published papers showed that immobilisation technique based on direct adsorption or on protein A coating, resulted in appropriate sensor signals, but only crosslinker procedures using thiols or the interaction between avidin and biotinylated molecules, provided a long sensor lifetime. Moreover, covalent coupling increased the stability against degradation during the regeneration process (Uttethaler et al., 1998). Generally, conventional immobilisation methods based on adsorption or covalent binding via the amino group of the protein are not site-directed and produce a random orientation of the antibody, which results in a very low binding efficiency (Vikholm et al., 1999).

V. vulnificus, which is halophilic and lactose-positive marine vibrio, causes severe wound infections, septicaemia, and gastroenteritis. Vibrio species are free-living bacteria found in aquatic environments throughout the world and also commonly isolated in samples from fish and shellfish, and, after concentration by filter-feeding shellfish such as oysters, may be present at concentrations that are 100-fold higher than those in the surrounding water. During warm summer months, virtually $100 \%$ of oysters will carry $V$. vulnificus and /or $V$. parahemolyticus. $V$. vulnificus is the leading cause of death with seafood consumption, which is the result of its ability to cause severe wound infections and sepsis in patients who are immunocompromised or have underlying liver disease. The majority of clinical and environmental $V$. vulnificus isolates reported to date are of biotype 1 .

In this study, an immunosensor was made to detect Vibrio vulnificus. This study explores antibody immobilisation method on the gold surface of quartz crystals, with the aim of improving antibody alignment and immunological activity, maximizing detection ability.

\section{Materials and methods}

\section{Chemicals}

Polyethylene imine (PEI) and 3-mercaptopropionic acid (MPA) were supplied from Sigma-Aldrich. Activating reagents including sulfide or imine on gold electrode, 1-ethyl-3-(3-dimethylaminopropyl), carboiimide hydrochloride (EDC), N-hydroxysulfosuccinimide (NHS), ethanolamine, hydrazine, cyanoborohydrate and glutaraldehyde were purchased from Sigma. The other reagents were analytical grade and doubly distilled water was used throughout the experiments.

Preparation of formalin killed cell of $\mathrm{V}$. vulnificus biotype 1 and antibody

V. vulnificus biotype 1 was kindly gifted from Prof. Jeong (Pukyoung National University, Korea) and cultured on tryptic soy agar (TSA) plate. A single colony was inoculated into $400 \mathrm{ml}$ of TSB medium and cultured overnight. Formalin at the final concentration of $1 \%$ was added to prepare formalin killed cell (FKC) and incubated for 24 hours at $4^{\circ} \mathrm{C}$. FKC was washed with phosphate buffered saline (PBS) several times before used as an antigen to prepare rabbit antiserum against $V$. vulnificus biotype 1. A rabbit was immunised with the prepared FKC and taken the antiserum when the titier was reached to 1:25600-51200. Rabbit IgG was purified using Protein G immobilised on highly cross-linked 4\% beaded agarose fast flow (Sigma), checked the purity on SDS-PAGE gel stained with Coomassie brilliant blue R250 and the protein concentration using BCA 
protein assay kit (Novagen).

\section{QCM biosensor system}

A 9MHz AT-cut piezoelectric wafer attached with two gold electrodes of $5 \mathrm{~mm}$ diameter had a reproducibility of $\pm 0.1 \mathrm{~Hz}$ in frequency response and was used as the transducer of the QCM biosensor in this study. It was mounted on a well holder made with acryl and connected to a home made oscillator module (Daga electronics, Korea). The analogue frequency signals from the oscillator were converted to the digital ones in a frequency counter. The in situ signal was stored in personal computer and performed data analysis using Microsoft excel program.

\section{Preparation of quartz crystals}

Piezoelectric quartz crystal was cleaned using piranha solution $\left(\mathrm{H}_{2} \mathrm{SO}_{4}: \mathrm{H}_{2} \mathrm{O}_{2}=7: 3\right)$ at $60^{\circ} \mathrm{C}$ for $5 \mathrm{~min}$ and rinsed with absolute ethanol and distilled water.

Indirect Immobilization of the antibody via proteinG on PEI layer or MPA

The quartz crystal was treated with $2 \%$ of PEI (polyethyleneimine) and then activated with $0.2 \%$ glutaraldehyde (Fig. 1A) or treated with $10 \mathrm{mM}$ of MPA (3-mercaptopropionic acid) and then activated with $46 \mathrm{mM}$ of EDC/NHS (Fig. 1B). Protein G (5 $\mathrm{mg} / \mathrm{ml}$ ) was cross-linked on the activated gold surface and uncross-linked residues were blocked by $5 \%$ Bovine serum albumin (BSA) in PBS and then antibody $(0.5 \mathrm{mg} / \mathrm{ml})$ was added. Thus antibody was immobilised on the quartz through protein $\mathrm{G}$.

\section{Direct Immobilization of the antibody through} amino residue coupled to EDC/NHS activated SAM layer

The quartz crystal was treated with $10 \mathrm{mM}$ of MPA (3-mercaptopropionic acid) and then activated with 46 $\mathrm{mM}$ of EDC/NHS. Hydrazide was cross-linked on the activated gold surface and uncross-linked residues were blocked by ethanolamine (MPA). Periodic acid treated antibody $(0.5 \mathrm{mg} / \mathrm{ml})$ whose aldehyde residues in carbohydrate ring within $\mathrm{Fc}$ region was exposured. The $\mathrm{Fc}$ region of antibody was immobilised on the gold surface through amino residues of hydrazide with right direction.

\section{Measurement of frequency changes}

To test adsorption level of each substance, $100 \mu \mathrm{l}$ of PBS was added into the reaction cell of the well holder and measured the resonant frequency until a steady-state baseline was obtained (F1) before incubating a sample in the reaction cell. After washing out unbound substances with PBS several times, 100ul of PBS was added into the reaction cell and the steady-state resonant frequency (F2) was read again to calculate the frequency shift $(\triangle F=F 1-F 2)$.

\section{Dose response of the sensor system prepared by direct cross-linking}

For the dose response, bacterial cell (FKC) was applied at the various dose of $0.01,0.1,1,1,10 \mathrm{mg} / \mathrm{ml}$ and frequency shifts were counted for $5 \mathrm{~min}$.

\section{Results and Discussion}

Anti-V. vulnificus antibody immobilization via cross-linked protein $\mathrm{G}$

In this study, immunosensor system to detect a foodborn pathogenic bacteria $V$. vulnificus was constructed by immobilizing anti- $V$. vulnificus antibody over the gold electrode of the quartz crystal. Concerning the orientation of antibody for the best antigen binding capacity, the antibody was immobilized by cross-linking through hydrazine or by specific binding protein $\mathrm{G}$ cross-linked on EDC/NHS activated sulfide monolayer (MPA) or glutaraldehyde activated immine layer (PEI). The injection of protein $\mathrm{G}$, BSA and IgG on activated sulfide monolayer or immine layer caused the frequency shift of $293.75 \pm$ 54.4 and $235 \pm 25.4,271.5 \pm 15.9$ and $229.8 \pm 11.3,143 \pm$ 16.6 and $64.25+9.27 \mathrm{~Hz}$ (mean \pm S.E.), respectively 
(Fig. 1). These results revealed that PEI was more effective to immobilize protein $G$ following glutaraldehyde activation than MPA.

However, when the antigen was added at the con- centration of $100 \mathrm{mg} / \mathrm{ml}$, the frequency shift was $103 \pm 4$ and $89 \pm 12 \mathrm{~Hz}$, respectively. This is interesting because the frequency change was more the 2 times higher in PEI method but the detection ability is not

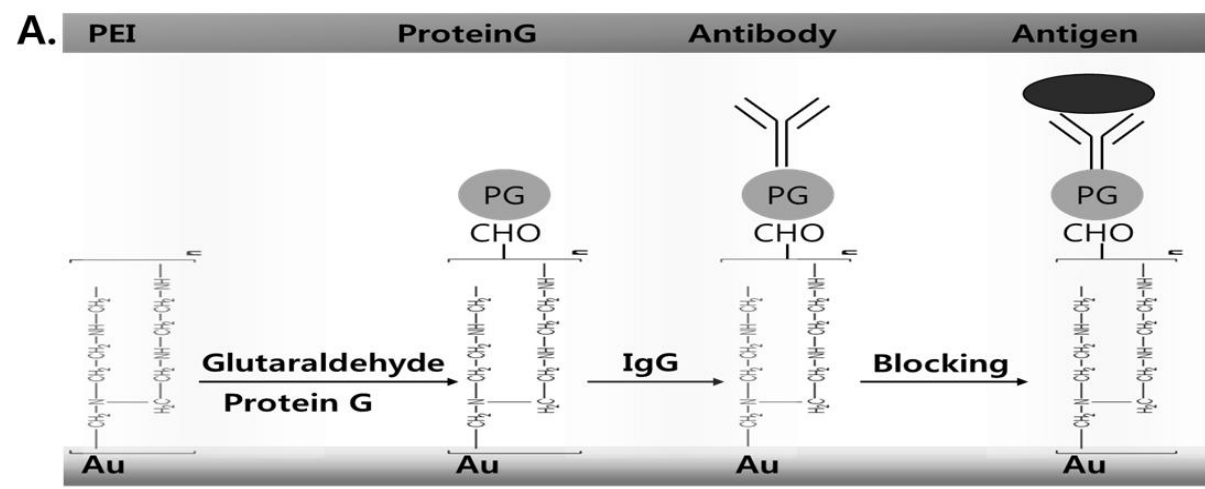

B.

Antigen<smiles>O</smiles><smiles>C1CCCCC1</smiles><smiles>C1CC2CC12</smiles>

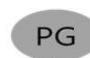<smiles>C1CCNC1</smiles>

4<smiles>C=C1C=CC=C1</smiles><smiles>[CH-]1CC[TeH2]C1</smiles><smiles>NC1=CC1</smiles>

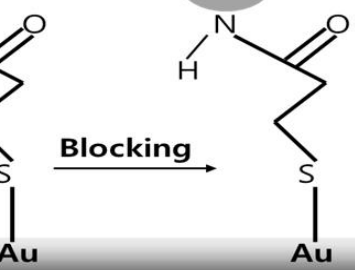

C.

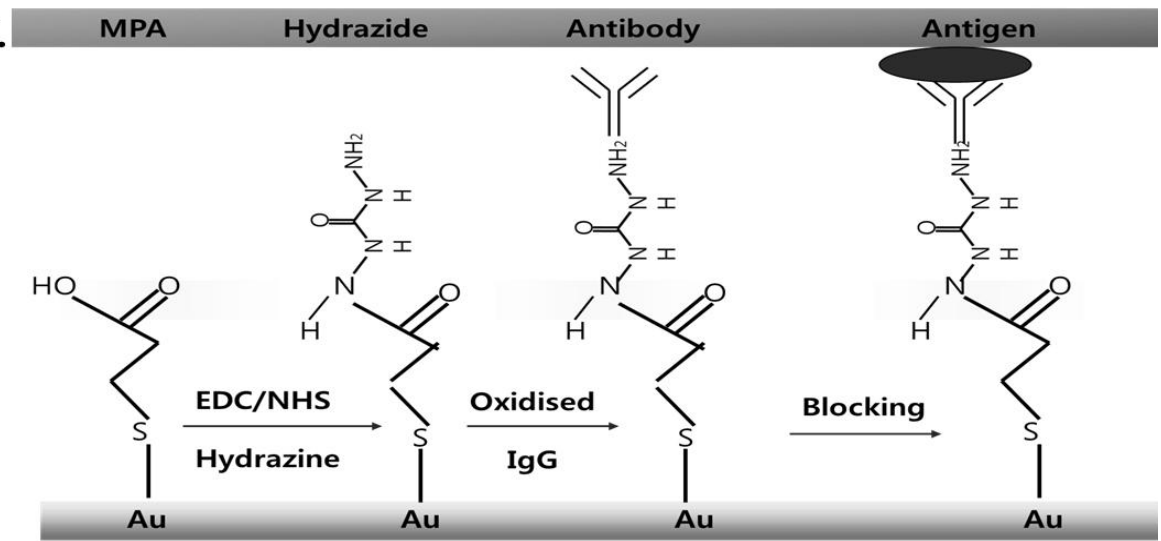

Fig. 1. Scheme of IgG immobilisation methods. A. PEI chip was prepared to immobilize protein $G(P G)$ and then IgG was immobilized. After blocking with BSA, antigen was detected on the immuno sensor chip. B.MPA chip was prepared and activated by EDC/NHS to immobilize protein $\mathrm{G}$ (PG). IgG was immobilized on the protein $\mathrm{G}$ and blocked with ethanol amine and BSA. C. MPA chip was prepared and activated by EDC/NHS. Then hydrazine was reacted to immobilize oxidised IgG. Non-specific binding was blocked with ethanol amine and BSA. 
that different in PEI and MPA. This means the immobilized antibodies were not fully able to detect the pathogen. This might be because of the binding property of protein G. Protein $\mathrm{G}$ is known to bind to Fc region of $\operatorname{IgG}$ and this is the reason why it was used for IgG immobilization. However, it is also known to bind to Fab region of IgG and, in that case, the ability of antigen binding capacity of $\operatorname{IgG}$ can be reduced.

\section{Anti- $V$. vulnificus antibody immobilization by direct cross-linking}

In this study, a direct immobilizing technique was introduced using oxidized antibody concerning the orientation of antibody for the best antigen binding capacity. The antibody was immobilized by crosslinking through hydrazine cross-linked via EDC/NHS activation of the sulfide monolayer (MPA), and then assessed immobilisation ability and sensitivity, comparing with protein $\mathrm{G}$ chip on PEI. The injection of IgG and bacterial cells onto protein $\mathrm{G}$ chip or hydrazine chip caused the frequency shift of $143 \pm 16.6$ and $474.6 \pm 7.7,103 \pm 4$ and 217.25 \pm 2.9 , respectively (Fig. 2). This result reveals that the direct immobilization

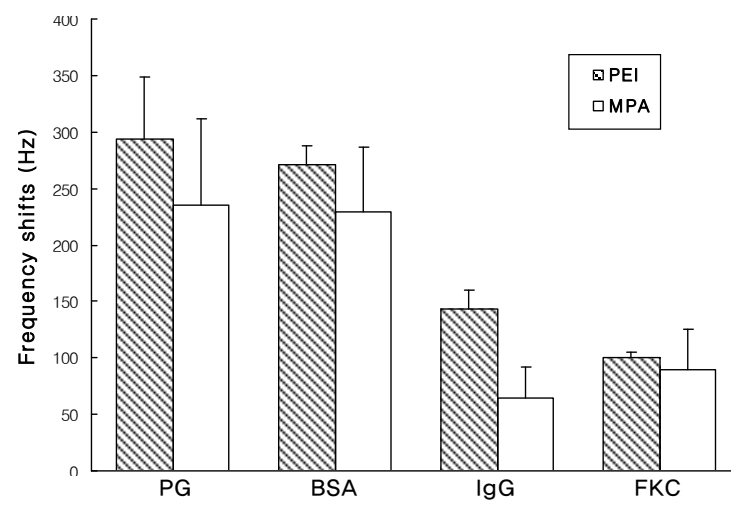

Fig. 2. Assessment of surface creating methods to prepare protein G chip. ProteinG was immobilised on PEI or SAM activated by glutaraldehyde or EDC/NHS, respectively. Both methods immobilise the N-terminal of protein G. BSA was used as a blocking agent and 100 $\mathrm{mg} / \mathrm{ml}$ of bacterial cell was tested. of $\mathrm{IgG}$ is about 3 times more efficient to immolize IgG than the indirect immobilization using protein $\mathrm{G}$ and the sensitivity was also more than 2 times higher. Though it can be thought that the amount of protein $\mathrm{G}$ was not enough to immobilize more IgGs, the direct immobilization method is definitely more efficient if the price of protein $\mathrm{G}$ and regeneration process was considered.

Dose response of the sensor system prepared by direct cross-linking

Bacterial cell (FKC) was applied at the various

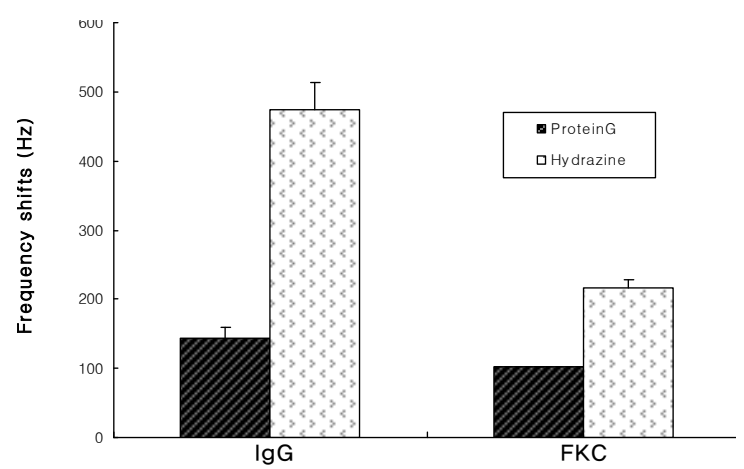

Fig. 3. Assessment of immobilisation ability and sensitivity of protein $\mathrm{G}$ chip on PEI and hydrazine chip on MPA. IgG was immobilised on protein G chip or oxidised IgG was immobilised on hydrazine chip at the same concentration of $0.5 \mathrm{mg} / \mathrm{ml}$.

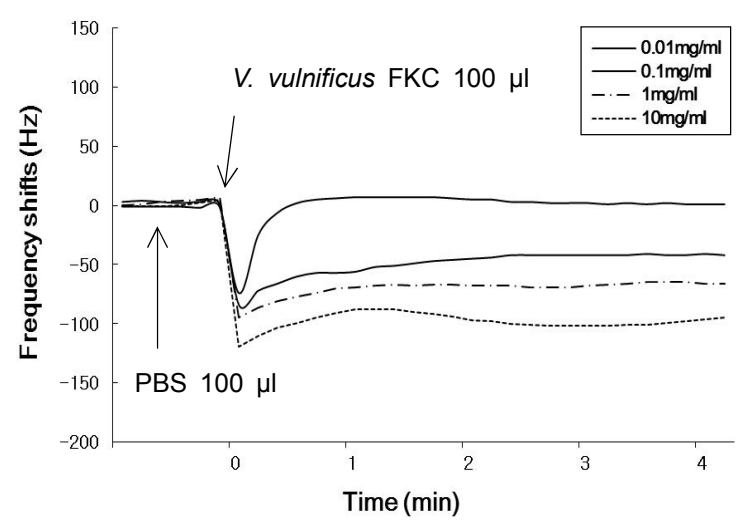

Fig. 4. Dose response of the sensor system. Bacterial cell (FKC) was applied at the various dose of 0.01 to $10 \mathrm{mg} / \mathrm{ml}$ and frequency shifts were plotted. 
dose of 0.01 to $100 \mathrm{mg} / \mathrm{ml}$ and increased frequency shifts in dose dependant manner. Since signal at 0.01 $\mathrm{mg} / \mathrm{ml}$ was too low, the detection limit of the sensor system seemed to be between 0.1 and $0.01 \mathrm{mg} / \mathrm{ml}$. Bacterial cell numbers is corresponding to $0.01 \mathrm{mg}$ is $10^{7}$ cells. Because we used $0.1 \mathrm{ml}$, detection limit of the sensor system will be higher than $10^{6}$ cells. This sensitivity is not very high but can be improved by stabilising the signal and enrichment of bacteria by preculture before applying to the sensor system.

\section{Conclusion}

In conclusion we have developed a biosensor system for the detection of $V$. vulnificus biotype I using QCM immunosensor system. We have first tested antibody immobilization methods and found that the method immobilizing oxidized IgG on hydrazine chip was more efficient to immobilize $\operatorname{IgG}$ and to detect pathogen. Using this method the sensor system was able to detect $V$. vulinificus in dose dependent manner and the detection limit of the sensor system seemed to be between 0.1 and $0.01 \mathrm{mg} / \mathrm{ml}$. These results reveal that the QCM immunosensor system can be developed as a promising diagnostic device for the rapid detection of aquatic pathogenic bacteria.

\section{Acknowledgement}

This research was supported by Korea Institute of Marine Science \& Technology Promotion (PJT200599).

\section{References}

Absolom, D.,R., Zingg, W. and Neumann, A. W. Protein adsorption to polymer particles: role of surface properties. J. Biomed. Mater. Res. 21: 161-171, 1987.

Attili, B. S. and Suleiman, A. A. A piezoelectric immunosensor for the detection of cortisol. Anal. Lett. 28: 2149-2159, 1995.

Bao, L., Deng, L., Nie, L., Yao, S., Wei, W., Determination of microorganisms with a quartz crystal microbalance sensor. Anal. Chim. Acta 319: 97-101, 1996.
Ben-Dov, I., Willner, I., Zisman, E., Piezoelectric immunosensors for urine specimens of ChlamydiaTrachomatis emploting quartz-crystal microbalance microgravimetric analyses. Anal. Chem. 69(17): 35063512, 1997.

Boveniser, J. S., Jacobs, M. B., Guilbault, G. G. and O'Sullivan, C. K. The detection of Pseudomonas aeruginosa using the quartz crystal microbalance. Anal. Lett., 31: 1287-1295, 1998.

Bunde, R. L., Jarvi, E. J. and Rosentreter, J. J. Piezoelectric quartz crystal biosensors. Talanta, 46, pp. 12231236, 1998.

Clark, D. J., Blake-Coleman, B. C., and Calder, M. R. Principles and potential of piezo-electric transducers and acoustical techniques, in Biosensors : fundamentals and Application(Turner, A. P. F., Karube, I., and Wilson, G.S., eds.), Oxford University press, Oxford, pp 551-571, 1987.

Guilbault, G. G., Hock, B. and Schmid, R. A Piezoelectric Immunobiosensor for Atrazine in Drinking Water" Biosensors Bioelectronics 7: 411-420, 1992.

Horisberger, M. and Vauthey, M. Labelling of colloidal gold with protein a quantitative study using $\beta$-lactoglobulin, Histochemistry 80(1): 13-19, 1984.

Koenig, B., Gratzel, M., Detection of viruses and bacteria with piezoelectric immunosensors. Anal. Lett. 26(8): 1567-1585, $1993 \mathrm{~b}$.

Koening, B., Gratzel, M. Detection of human T-Lymphocytes with a Piezoelectric immunosensor Anal. Chim. Acta 281: 13-18, 1993a.

König, B. and Grätzel, M. Human granulocytes detected with a piezoimmunosensor. Anal. Letters, 26(11): 2313-2328, 1993.

Konig, B. and Gratzel, M. A novel immunosensor for herpes viruses, Anal. Chem. 66: 341, 1994.

Lin, Z., Yip, C. M., Joseph, I. S. and Ward, M. D. Operation of an Ultrasensitive 30-MHz Quartz Crystal Microbalance in Liquids, Anal. Chem. 65: 1546-1551, 1993.

Matsumura, H. and Kleijn, J. M. Admittance measurements on protein layers adsorbed at the $\mathrm{Pt} /$ solution interface: effect of d.c. potential and a.c. field. Colloids and surfaces. B, Biointerfaces, 277-282, 1993.

Minunni, M., Mascini, M., Guilbault, G. G. and Hock, B. The Quartz Crystal Microbalance as Biosensor. A Status Report.; Anal. Letters, 28: 749-764, 1995. Muramatsu, H., Dicks, J. M., Tamia, E. and Karube, I. 
Piezoelectric Crystal Biosensor Modified with Protein A for Determination of Immunoglobulins. Analytical Chemistry, 59: 2760-2763, 1987.

Muramatsu, H., Kajiwara, K., Tamiya, E., Karube, I. Piezoelectric immunosensor for the detection of Candida albicans microbes. Anal. Chim. Acta 188: 257-261, 1986.

Plomer, M., Guilbault, G.G., Hock, B. Development of a piezoelectric immunosensor for the detection of Enterobacteria. Enzyme Microb. Technol. 14: 230235, 1992.

Prusak-Sochaczewski E, Luong, J. H. and Guilbault, G. G. Development of a piezoelectric immunosensor for the detection of Salmonella typhimurium. Enzyme Microb Technol., 12(3): 173-177, 1990.

Shons, A., Dorman and F. Najarian, J. An immunospecific microbalance, J. Biomed. Mater. Res., 6: 565-570, 1972.

Skladal, P., Minunni, M., Mascini, M., Kolar, V., and Franek, M. Characterization of Monoclonal-Anti- bodies to 2,4-Dichlorophenoxyacetic Acid Using A Piezoelectric Quartz-Crystal Microbalance in Solution. J. Immunol. Methods 176: 117-125, 1994.

Sjobring, U., Bjork, L., and Kastern, W. Streptoccocal protein G: gene structure and protein binding properties. J. Biol. Chem., 266(1): 399-405, 1991.

Steegborn, C. and Skládal, P. Construction and characterisation of the direct piezoelectric immunosensor for atrazine operating in solution. Biosens. Bioelectron, 12, 19-27, 1997.

Uttenthaler, E., Kosslinger, C. and Drost, S. Characterization of immobilization methods for African swine fever virus protein and antibodies with a piezoelectric immunosensor. Biosens. Bioelectron., 13: 1279-1286, 1998.

Vikholm, I., Viitala, T., Albers, W. M. and Peltonen, J. Highly efficient immobilisation of antibody fragments to functionalised lipid monolayers, Biochim. Biophys. Acta., 1421: 39-52, 1999. 